\title{
Pengaruh Sistem Administrasi Perpajakan Modern, Pengetahuan Perpajakan Dan Kualitas Pelayanan Fiskus Pada Kepatuhan WPOP
}

\author{
Ni Putu Yunita Sari ${ }^{1}$ \\ I Ketut Jati ${ }^{2}$ \\ ${ }^{1,2}$ Fakultas Ekonomi dan Bisnis Universitas Udayana (Unud), Bali, Indonesia \\ e-mail: putuyunitasari97@gmail.com
}

\begin{abstract}
ABSTRAK
Penelitian ini bertujuan untuk mengetahui pengaruh sistem administrasi perpajakan modern, pengetahuan perpajakan, dan kualitas pelayanan fiskus pada kepatuhan wajib pajak orang pribadi di Kantor Pelayanan Pajak Pratama Denpasar Timur. Populasi dalam penelitian ini adalah seluruh wajib pajak orang pribadi yang terdaftar di Kantor Pelayanan Pajak Pratama Denpasar Timur. Jumlah sampel yang digunakan dalam penelitian ini adalah sebanyak 100 responden dari 76.543 populasi wajib pajak orang pribadi yang masih efektif di Kantor Pelayanan Pajak Pratama Denpasar Timur pada tahun 2017. Besarnya sampel dihitung berdasarkan rumus slovin dengan teknik penentuan sampel metode insidental sampling. Pengumpulan data dalam penelitian ini dilakukan dengan metode kuesioner. Teknik analisis data yang digunakan adalah analisis regresi linear berganda. Hasil penelitian menunjukkan bahwa sistem administrasi perpajakan modern, pengetahuan perpajakan, dan kualitas pelayanan fiskus berpengaruh positif terhadap tingkat kepatuhan wajib pajak orang pribadi. Kata kunci: perpajakan modern, pengetahuan, pelayanan fiskus, kepatuhan
\end{abstract}

\begin{abstract}
This study aims to determine the system of modern tax administration, knowledge, and service quality. Tax facilitator at the East Denpasar Primary Tax Office. The population in this study were all taxpayers registered at the Pratama East Tax Office. The number of samples used in this study were 100 respondents from 76,543 people who were still working at the East Denpasar Pratama Tax Office in 2017. The sample size was calculated based on the formula with incidental sampling technique. Data collection in this study was conducted by questionnaire method. Data analysis techniques that are multiple linear regression analysis. The results of the study show that the modern tax administration system, knowledge, and quality of taxpecting services are positive for the individual taxpayer tax rate.
\end{abstract}

Keywords: modern taxation, knowledge, fiscus service, compliance

\section{PENDAHULUAN}

Salah satu sumber penerimaan terbesar negara, khususnya Negara Kesatuan Republik Indonesia berasal dari pajak. Menurut Undang-Undang No. 16 Tahun 2009 tentang Ketentuan Umum dan Tata Cara Perpajakan Pasal 1 ayat (1) menyebutkan bahwa "Pajak adalah kontribusi wajib kepada negara yang terutang oleh orang pribadi atau badan yang bersifat memaksa berdasarkan Undang- 
Ni Putu Yunita Sari dan I Ketut Jati. Pengaruh...

Undang, dengan tidak mendapatkan imbalan secara langsung dan digunakan untuk keperluan negara bagi sebesar-besarnya kemakmuran rakyat”. Penerimaan dari sektor pajak dapat menjadi alat untuk menopang jalannya perekonomian suatu negara. Mengingat pentingnya peranan pajak sebagai sarana untuk membiayai berbagai macam pengeluaran negara, pemerintah dalam hal ini Direktorat Jenderal Pajak terus berupaya untuk mengoptimalkan penerimaan pajak. Penerimaan dari sektor pajak akan meningkat apabila didukung oleh kepatuhan wajib pajak. Konsep kepatuhan wajib pajak didefinisikan sebagai sikap positif yang timbul dari dalam diri individu terhadap kesediaannya untuk membayar pajak (Helhel dan Ahmed, 2014). Kepatuhan wajib pajak mengacu pada pemenuhan kewajiban perpajakan dalam rangka memberikan kontribusi bagi negara yang diharapkan dalam pemenuhannya diberikan secara sukarela (Serem et al., 2017).

Seiring dengan perkembangan zaman yang semakin modern dan pesatnya perkembangan teknologi, memudahkan wajib pajak untuk mengakses berbagai sumber informasi dan pelayanan perpajakan melalui berbagai saluran. Terlepas dari hal tersebut, tunggakan pajak masih saja terus terjadi. Fenomena yang terjadi saat ini adalah sebanyak 2.961 wajib pajak tercatat melakukan penunggakan pajak sepanjang tahun 2006-2017. Hal tersebut berdasarkan laporan dari Pusat Pelaporan dan Analisis Transaksi Keuangan/PPATK (Deny, 2017). Penyebab terjadinya tunggakan pajak tersebut, dikarenakan rendahnya pengetahuan dan pemahaman sebagian besar wajib pajak mengenai sistem perpajakan, sering terjadi kendala dari segi teknis dalam sistem online, serta rendahnya kualitas 
pelayanan fiskus sehingga mempengaruhi kepatuhan wajib pajak dalam memenuhi kewajiban perpajakannnya.

Di provinsi Bali sendiri, tingkat kepatuhan wajib pajak dari tahun ke tahun mengalami fluktuasi, kendatipun Bali merupakan destinasi tujuan utama pariwisata yang sekaligus menjadi penyumbang pajak terbesar dari sektor pariwisata. Hal tersebut dapat dibuktikan dengan data yang diperoleh dari Kantor Pelayanan Pajak (KPP) Pratama Denpasar Timur. KPP Pratama Denpasar Timur merupakan instansi vertikal Direktorat Jenderal Pajak yang membawahi wilayah Kecamatan Denpasar Timur dan Kecamatan Denpasar Selatan, sehingga KPP Pratama Denpasar Timur memiliki jumlah wajib pajak terdaftar yang cukup besar. Tabel 1 menyajikan data tingkat kepatuhan wajib pajak orang pribadi yang terdaftar di KPP Pratama Denpasar Timur periode 2013 sampai dengan 2017.

\section{Tabel 1.}

Tingkat Kepatuhan Wajib Pajak Orang Pribadi di Kantor Pelayanan Pajak Pratama Denpasar Timur Tahun 2013-2017

\begin{tabular}{lccccc}
\hline No. & Tahun & WPOP Terdaftar & $\begin{array}{c}\text { WPOP } \\
\text { Efektif }\end{array}$ & $\begin{array}{c}\text { WPOP yang } \\
\text { Menyampaikan } \\
\text { SPT }\end{array}$ & $\begin{array}{c}\text { Kepatuhan } \\
\text { Pajak \% }\end{array}$ \\
\hline 1. & 2013 & 91.440 & 71.928 & 36.386 & 50,58 \\
2. & 2014 & 83.926 & 64.405 & 35.820 & 55,61 \\
3. & 2015 & 87.652 & 68.124 & 36.928 & 54,20 \\
4. & 2016 & 91.048 & 71.554 & 41.175 & 57,54 \\
5. & 2017 & 96.073 & 76.543 & 38.647 & 50,49 \\
\hline \multicolumn{5}{l}{ Sumber: KPP Pratama Denpasar Timur, 2018}
\end{tabular}

Berdasarkan Tabel 1 terlihat bahwa persentase kepatuhan wajib pajak orang pribadi yang berada di lingkungan KPP Pratama Denpasar Timur mengalami fluktuasi selama lima tahun terakhir. Persentase kepatuhan di tahun 2013 sebesar $50,58 \%$ meningkat menjadi 55,61\% pada tahun 2014. Namun, di tahun 2015 mengalami penurunan menjadi 54,20\%. Kemudian di tahun 2016 meningkat lagi 
Ni Putu Yunita Sari dan I Ketut Jati. Pengaruh...

menjadi 57,54\%, tetapi di tahun 2017 mengalami penurunan menjadi 50,49\%. Dapat disimpulkan, persentase kepatuhan wajib pajak orang pribadi yang terdaftar di KPP Pratama Denpasar Timur dalam rentang waktu lima tahun terakhir berada pada kisaran 50\%. Hal ini mengindikasikan bahwa tingkat kepatuhan wajib pajak masih rendah. Rendahya tingkat kepatuhan wajib pajak adalah masalah yang serius yang sering terjadi di banyak negara berkembang (Das-gupta, 2004).

Berdasarkan kondisi tersebut, maka pemerintah melalui Direktorat Jenderal Pajak yang berada di bawah Kementrian Keuangan terus melakukan upaya-upaya agar pengelolaan penerimaan pajak semakin baik. Upaya tersebut dapat dilakukan dengan kebijakan perpajakan maupun administrasi perpajakan. Melalui kebijakan perpajakan Direktorat Jenderal Pajak berupaya memperbaharui kebijakankebijakan perpajakan yang tertuang dalam undang-undang perpajakan, sedangkan melalui administrasi perpajakan, Direktorat Jenderal Pajak berupaya memperbaharui sistem internal Direktorat Jenderal Pajak agar dapat memberikan pelayanan yang terbaik bagi wajib pajak (Savilla et al., 2018).

Semenjak tahun 2002, Direktorat Jenderal Pajak (DJP) telah meluncurkan program perubahan (change program) atau reformasi administrasi perpajakan yang secara singkat biasa disebut modernisasi. Perubahan yang dilakukan oleh DJP adalah pada bidang proses bisnis dan teknologi informasi dan komunikasi. Perbaikan proses bisnis yang dilakukan antara lain, penerapan e-system dengan dibukanya fasilitas $e$-filling (pengiriman SPT secara online), $e$-SPT (penyerahan SPT dalam media digital), e-billing (pembayaran pajak secara online) dan $e$ registration (pendaftaran NPWP secara online). Dengan adanya modernisasi 
diharapkan dapat meningkatkan kepatuhan wajib pajak dan menghapus inefisiensi yang terkait dengan biaya pergerakan yang dilakukan oleh wajib pajak (Maisiba dan Atambo, 2016).

Sistem administrasi perpajakan modern dapat digolongkan sebagai faktor eksternal yang mempengaruhi wajib pajak untuk melaksanakan kepatuhan perpajakannya (Ameur dan Tkiouat, 2016). Hal tersebut selaras dengan penelitian yang dilakukan oleh Anggraeni (2016) yang menyatakan sistem administrasi perpajakan modern (struktur organisasi, strategi organisasi, prosedur organisasi, dan budaya organisasi) bepengaruh terhadap kepatuhan wajib pajak. Pernyataan tersebut diperkuat juga dengan penelitian yang dilakukan oleh Çevik \& Yeniçeri (2013) dimana hasil penelitiannya menyatakan bahwa efisiensi administrasi perpajakan ditemukan memiliki pengaruh moderat yang signifikan terhadap hubungan antara norma sosial dan kepatuhan pajak. Bertolak belakang dengan penelitian yang dilakukan oleh Arifah et al. (2017) yang menyatakan bahwa modernisasi sistem administrasi perpajakan tidak berpengaruh terhadap kepatuhan wajib pajak.

Suksesnya penerapan sistem administrasi perpajakan modern tidak terlepas dari pengetahuan perpajakan yang dimiliki oleh wajib pajak, berkenaan dengan itu pengetahuan wajib pajak juga dianggap sebagai salah satu faktor yang berpengaruh terhadap kepatuhan wajib pajak. Kasippilai (2000) menyatakan bahwa pengetahuan pajak dapat meningkatkan kepatuhan wajib pajak. Hal tersebut didukung oleh hasil penelitian Santoso (2015) yang menyatakan bahwa pengetahuan wajib pajak berpengaruh positif terhadap kepatuhan wajib pajak. 
Ni Putu Yunita Sari dan I Ketut Jati. Pengaruh...

Bertolak belakang dengan penelitian Andinata (2015) yang menunjukkan bahwa pengetahuan serta pemahaman tentang peraturan perpajakan tidak memiliki pengaruh terhadap kepatuhan wajib pajak.

Demi terwujudnya realisasi penerimaan pajak yang maksimal, selain didukung dengan pengetahuan perpajakan yang dimiliki oleh wajib pajak itu sendiri, salah satu upaya yang dapat dilakukan adalah dengan memberikan pelayanan yang baik kepada wajib pajak. Peningkatan kepatuhan masyarakat dibidang perpajakan juga harus ditunjang dengan kualitas pelayanan fiskus yang mendukung peningkatan peran aktif masyarakat serta pemahaman akan hak dan kewajibannya dalam melaksanakan peraturan perundang-undangan perpajakan. Pelayanan fiskus yang baik akan memberikan kenyamanan bagi wajib pajak.

Namun kenyataannya, masih ada wajib pajak yang menemukan hambatan dalam proses pelayanan yang diberikan oleh aparatur perpajakan, seperti petugas yang lambat, tidak ramah, berbelit-belit, serta keadaan kantor dan layanan yang kurang nyaman, sehingga menimbulkan berbagai keluhan, dan pada akhirnya berakibat pada tumbuhnya sikap tidak patuh dalam melaksanakan kewajiban perpajakan (Hidayatulloh, 2013). Beberapa penelitian tentang kepatuhan wajib pajak dengan kualitas pelayanan fiskus sebagai variabel indepennya telah dilakukan oleh peneliti sebelumnya. Syahril (2013) dan Kusuma (2016) dalam penelitiannya menyatakan kualitas pelayanan memiliki pengaruh positif terhadap kepatuhan wajib pajak. Berbeda dengan penelitian Wirenungan (2013) menyatakan bahwa pelayanan fiskus tidak memiliki pengaruh terhadap kepatuhan wajib pajak orang pribadi. 
Berdasarkan kondisi realita tingkat kepatuhan wajib pajak di Indonesia saat ini, serta adanya research gap dari penelitian sebelumnya, maka penulis termotivasi untuk melakukan penelitian dengan judul "Pengaruh Sistem Administrasi Perpajakan Modern, Pengetahuan Perpajakan, dan Kualitas Pelayanan Fiskus pada Kepatuhan Wajib Pajak Orang Pribadi”. Adapun rumusan masalah dalam penelitian ini yaitu, apakah sistem administrasi perpajakan modern, pengetahuan perpajakan, dan kualitas pelayanan fiskus berpengaruh pada kepatuhan wajib pajak orang pribadi di Kantor Pelayanan Pajak Pratama Denpasar Timur?

Penelitian ini diharapkan dapat memberikan manfaat baik dari segi teoritis maupun praktis. Adapun manfaat teoritisnya dimana penelitian ini mampu memberikan bukti empiris tentang manfaat teori atribusi untuk mendukung kepatuhan wajib pajak orang pribadi dengan cara meningkatkan sistem administrasi perpajakan modern, pengetahuan perpajakan, dan kualitas pelayanan fiskus. Selanjutnya, untuk manfaat praktis penelitian ini mampu memberikan informasi bagi wajib pajak orang pribadi untuk meningkatkan kepatuhan pajak dan bagi Direktorat Jenderal Pajak dalam mengambil keputusan serta menentukan kebijakan di masa yang akan datang terkait dengan kepatuhan wajib pajak sehingga nantinya dapat meningkatkan kinerja organisasi.

Teori Atribusi menjelaskan bahwa ketika individu mengamati perilaku seseorang, individu tersebut berupaya untuk menentukan apakah perilaku yang timbul tersebut disebabkan secara internal atau eksternal (Robbins dan Judge, 2008). Teori atribusi relevan untuk menjelaskan penelitian ini, karena perilaku 
Ni Putu Yunita Sari dan I Ketut Jati. Pengaruh...

seseorang dalam memenuhi kewajiban perpajakannya disebabkan oleh berbagai faktor internal dan eksternal.

Menurut Rahayu (2010:138) kepatuhan perpajakan merupakan suatu keadaan dimana wajib pajak memenuhi semua kewajiban perpajakan dan melaksanakan hak perpajakannya. Kirchler dan Wahl (2010) menganggap bahwa kepatuhan adalah istilah paling netral dan inklusif yang menggambarkan kesediaan orang untuk membayar pajak.

Mardiasmo (2016:164) menyatakan bahwa subjek pajak orang pribadi dibedakan menjadi dua yaitu, subjek pajak dalam negeri dan subjek pajak luar negeri. Wajib pajak orang pribadi perlu untuk mendaftarkan diri di KPP untuk mendapatkan Nomor Pokok Wajib Pajak (NPWP). Selain itu, wajib pajak orang pribadi mempunyai kewajiban untuk melaporkan penghasilannya melalui SPT Tahunan dengan menggunakan sistem self-assessment.

Yamit (2002:9) menyatakan bahwa kualitas adalah kondisi dinamis yang terkait dengan produk layanan, orang, proses, dan lingkungan yang memenuhi atau melampaui harapan. Supadmi (2009) menyatakan untuk meningkatkan kepatuhan wajib pajak dalam memenuhi kewajiban perpajakannya, kualitas pelayanan pajak harus ditingkatkan oleh aparat pajak. Layanan dikatakan berkualitas jika memenuhi kriteria 4K yaitu, keamanan, kenyamanan, kelancaran, dan kepastian hukum. Kualitas layanan dapat diukur dengan kemampuan untuk memberikan layanan yang memuaskan dengan cara memberikan layanan dengan tanggapan, kemampuan, kesusilaan, dan kepercayaan yang dimiliki oleh otoritas pajak. Selain itu, kemudahan dalam membuat hubungan komunikasi yang baik, 
memahami kebutuhan wajib pajak, ketersediaan fasilitas fisik termasuk sarana komunikasi yang memadai, dan karyawan yang terampil dalam tugasnya (Safri, 2013).

Pengetahuan dapat diartikan sebagai suatu informasi yang diketahui oleh seseorang secara sadar melalui pengalaman atau pengamatan dengan inderanya (Hunt, 2003). Selanjutnya, menurut Carolina (2009) pengetahuan pajak adalah informasi pajak yang dapat digunakan wajib pajak sebagai dasar untuk bertindak, mengambil keputusan, dan untuk menempuh arah atau strategi tertentu sehubungan dengan pelaksanaan hak dan kewajibannya dibidang perpajakan.

Suparman (2007) mendefinisikan sistem administrasi perpajakan modern sebagai suatu penyempurnaan atau perbaikan kinerja administrasi baik secara individu, kelompok, maupun kelembagaan agar lebih efisien, ekonomis dan cepat. Administrasi pajak yang sukses mengharuskan pembayar pajak untuk bekerja sama dalam pengoperasian sistem pajak (James dan Alley, 2004).

Sistem administrasi perpajakan modern menurut teori atribusi merupakan penyebab eksternal yang dapat mempengaruhi perilaku wajib pajak dalam melaksanakan kewajiban perpajakannya. Jika wajib pajak dapat menerima pengaruh eksternal tersebut, maka akan semakin baik persepsi wajib pajak atas keberadaan sistem administrasi perpajakan modern yang berdampak pada meningkatnya kepatuhan wajib pajak.

Nasucha (2004:9) menyatakan bahwa: "Penerapan sistem administrasi perpajakan modern memiliki kaitan erat dengan kepatuhan wajib pajak di tinjau dari seberapa besar efektifitas pengukurannya". Modernisasi sistem administrasi 
Ni Putu Yunita Sari dan I Ketut Jati. Pengaruh...

didukung dengan pelayanan e-system yang disediakan oleh Direktorat Jenderal Pajak seperti e-Registration, e-SPT, e-Filing, e-Banking, e-Billing yang akan memudahkan wajib pajak dalam melaksanakan kewajibannya. Dapat disimpulkan bahwa sistem administrasi modern adalah sistem administrasi yang mengalami penyempurnaan atau perbaikan untuk meningkatkan pelayanan kepada wajib pajak dengan memanfaatkan teknologi informasi yang diharapkan dapat meningkatkan kepatuhan wajib pajak dan penerimaan pajak (Walsh, 2012). Hal tersebut sesuai dengan penelitian Fasmi dan Misra (2012), Rahmawati (2014), Khasanah (2014), dan Arifin (2015) yang menyimpulkan bahwa sistem administrasi perpajakan modern berpengaruh positif terhadap kepatuhan wajib pajak.

H1: Sistem administrasi perpajakan modern berpengaruh positif pada kepatuhan wajib pajak orang pribadi di Kantor Pelayanan Pajak Pratama Denpasar Timur.

Pengetahuan perpajakan menurut teori atribusi merupakan penyebab eksternal yang dapat mempengaruhi perilaku wajib pajak dalam melaksanakan kewajiban perpajakannya. Jika wajib pajak dapat menerima pengaruh eksternal tersebut, maka semakin luas pengetahuan tentang ketentuan umum dan tata cara perpajakan yang dapat dipahami oleh wajib pajak, dimana hal tersebut akan berdampak pada meningkatnya kepatuhan wajib pajak.

Pengetahuan pajak dapat diartikan sebagai tingkat kesadaran atau kepekaan para pembayar pajak terhadap peraturan pajak. Pengetahuan pajak mengacu pada proses, dimana pembayar pajak menjadi sadar akan undang-undang pajak dan informasi terkait pajak lainnya (Hasseldine et al., 2009). Pengetahuan 
pajak merupakan salah satu faktor yang dapat mempengaruhi kepatuhan wajib pajak. Hal tersebut selaras dengan penelitian yang dilakukan oleh Zuhdi et al. (2015) yang menyimpulkan bahwa pengetahuan perpajakan berpengaruh terhadap kepatuhan wajib pajak. Didukung pula oleh penelitian yang dilakukan Oladipupo dan Obazee (2016), serta Saad (2014) yang juga menyimpulkan bahwa pengetahuan perpajakan berpengaruh terhadap kepatuhan wajib pajak.

$\mathrm{H}_{2}$ : Pengetahuan perpajakan berpengaruh positif pada kepatuhan wajib pajak orang pribadi di Kantor Pelayanan Pajak Pratama Denpasar Timur.

Kualitas pelayanan fiskus menurut teori atribusi merupakan penyebab eksternal yang dapat mempengaruhi perilaku wajib pajak dalam melaksanakan kewajiban perpajakannya. Jika wajib pajak dapat menerima pengaruh eksternal tersebut, maka akan menimbulkan dampak positif yaitu kerelaan dari wajib pajak dalam melaksanakan kewajibannya perpajakannya.

Terciptanya kondisi pelayanan yang lebih baik dan cepat yang diberikan oleh fiskus selama berjalannya proses perpajakan berkaitan dengan sikap wajib pajak dalam melaksanakan kewajiban perpajakannya. Menurut Yuliasari (2015) wajib pajak secara konsisten akan meningkatkan kepatuhannya bila didukung dengan pelayanan yang baik oleh aparat perpajakan. Hal tersebut selaras dengan penelitian yang dilakukan oleh Murti (2014) yang menyimpulkan bahwa pelayanan fiskus berpengaruh secara signifikan terhadap kepatuhan wajib pajak orang pribadi. Didukung pula oleh penelitian Prananti dan Rasmini (2014), serta Astina dan Setiawan (2018) yang menyimpulkan bahwa kualiats pelayanan fiskus berpengaruh positif terhadap tingkat kepatuhan wajib pajak. 
Ni Putu Yunita Sari dan I Ketut Jati. Pengaruh...

$\mathrm{H}_{3}$ : Kualitas pelayanan fiskus berpengaruh positif pada kepatuhan wajib pajak orang pribadi di Kantor Pelayanan Pajak Pratama Denpasar Timur.

\section{METODE PENELITIAN}

Pendekatan yang digunakan pada penelitian ini adalah pendekatan kuantitatif yang berbentuk asosiatif. Sugiyono (2017:37) menyatakan bahwa penelitian berjenis asosiatif merupakan penelitian yang bertujuan untuk mengetahui hubungan antara dua variabel atau lebih. Penelitian ini dilakukan di wilayah Denpasar serta untuk pengumpulan datanya dilakukan di Kantor Pelayanan Pajak (KPP) Pratama Denpasar Timur yang beralamat di Jalan Letda Tantular No.4 Renon, Denpasar. Pada penelitian ini, obyek penelitiannya ialah kepatuhan wajib pajak orang pribadi di KPP Pratama Denpasar Timur yang dipengaruhi oleh sistem administrasi perpajakan modern, pengetahuan perpajakan, dan kualitas pelayanan fiskus.

Terdapat dua variabel yang digunakan dalam penelitian ini yaitu variabel dependen (terikat) dan variabel independen (bebas). Adapun variabel dependen (Y) yang digunakan dalam penelitian ini yaitu kepatuhan wajib pajak orang pribadi, sedangkan variabel independen yang digunakan diantaranya sistem administrasi perpajakan modern $\left(\mathrm{X}_{1}\right)$, pengetahuan perpajakan $\left(\mathrm{X}_{2}\right)$, dan kualitas pelayanan fiskus $\left(\mathrm{X}_{3}\right)$. Skala pengukuran yang digunakan untuk masing-masing variabel adalah skala Likert modifikasi 4 poin dengan rincian sebagai berikut: a) Sangat Setuju (SS) diberi skor 4; b) Setuju (S) diberi skor 3; c) Tidak Setuju (TS) diberi skor 2; d) Sangat Tidak Setuju (STS) diberi skor 1. 
Populasi dalam penelitian ini adalah seluruh wajib pajak orang pribadi efektif yang terdaftar di KPP Pratama Denpasar Timur per 31 Desember 2017 sebanyak 76.543 orang. Sampel yang digunakan sebanyak 100 responden yang dihitung menggunakan rumus Slovin. Metode penentuan sampel dalam penelitian ini menggunakan teknik incidental sampling. Sampling insidental adalah teknik penentuan sampel berdasarkan kebetulan, yaitu siapa saja yang secara kebetulan/insidental bertemu dengan peneliti dapat digunakan sebagai sampel, bila dipandang orang yang kebetulan ditemui itu cocok dengan sumber data (Sugiyono, 2017). Metode pengumpulan data yang digunakan dalam penelitian ini adalah metode survey menggunakan media angket atau kuesioner.

Jenis data yang digunakan dalam penelitian ini adalah data kuantitatif dan data kualitatif. Data kuantitatif dalam penelitian ini berupa jumlah wajib pajak orang pribadi efektif di KPP Pratama Denpasar Timur dan hasil kuesioner yang merupakan jawaban dari responden, sedangkan data kualitatif yang digunakan berupa definisi atau gambaran umum serta tanggapan responden terhadap pernyataan-pernyataan yang terdapat dalam kuesioner. Data dalam penelitian ini bersumber dari data primer dan data sekunder. Dalam penelitian ini data primer yang dimaksud berupa jawaban dari kuesioner yang telah diisi oleh responden, sedangkan data sekunder yang dimaksud yaitu data-data yang diperoleh dari KPP Pratama Denpasar Timur berupa tingkat kepatuhan wajib pajak orang pribadi dan jumlah wajib pajak orang pribadi yang terdaftar, serta data yang diperoleh dari Pusat Pelaporan dan Analisis Transaksi Keuangan/PPATK dan Publikasi Statistik Indonesia. 
Ni Putu Yunita Sari dan I Ketut Jati. Pengaruh...

Teknik analisis data dalam penelitian ini diawali dengan uji instrumen penelitian terdiri dari uji validitas dan uji reliabilitas. Validnya suatu kuesioner dapat dilihat dari nilai $r$ hitung yang lebih besar dari 0,30 (Ghozali, 2016:55). Uji reliabilitas digunakan untuk mengukur konsistensi hasil pengukuran dari kuesioner dalam penggunaan yang berulang. Kuesioner dikatakan reliabel apabila nilai cronbach alpha yang diperoleh lebih besar dari 0,70 (Ghozali, 2016:43).

Analisis statistik deskriptif digunakan untuk menjelaskan deskripsi dari seluruh variabel yang akan dimasukkan dalam model penelitian yang dilihat dari nilai rata-rata (mean), standar deviasi, nilai minimum, nilai maksimum. Analisis statistik deskriptif dalam penelitian ini diukur dengan menggunakan program SPSS versi 24. Selanjutnya, pengujian gejala asumsi klasik dilakukan agar hasil analisis regresi memenuhi kriteria BLUE (Best, Linear, Unbiased Estimator). Uji asumsi klasik dalam penelitian ini terdiri dari uji normalitas, uji heteroskedastisitas dan uji multikolinearitas. Uji autokorelasi tidak dilakukan karena penelitian ini tidak berbentuk deret waktu.

Pengaruh sistem administrasi perpajakan modern, pengetahuan perpajakan, dan kualitas pelayanan fiskus terhadap kepatuhan wajib pajak orang pribadi dapat diketahui dengan melakukan analisis regresi linear berganda yang akan diuji dengan tingkat signifikansi. Model analisis regresi linear berganda dalam penelitian ini dapat dinyatakan dalam persamaan regresi sebagai berikut:

$$
\mathrm{Y}=\alpha+\beta_{1} \mathrm{X}_{1}+\beta_{2} \mathrm{X}_{2}+\beta_{3} \mathrm{X}_{3}+\mathrm{e}
$$

Keterangan :

$\mathrm{Y}=$ Kepatuhan Wajib Pajak Orang Pribadi

$\alpha=$ Konstanta

$\beta=$ Koefisien Regresi 


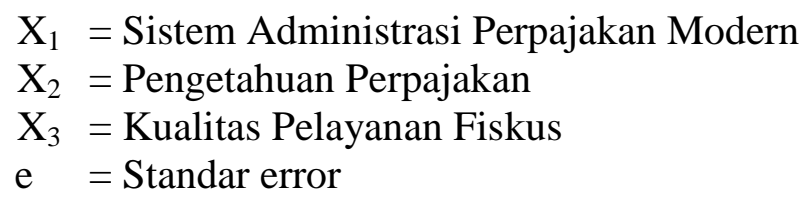

Uji Goodness of Fit dari analisis regresi linear berganda dapat diamati dengan menggunakan nilai koefisien determinasi, uji kelayakan model (uji F), dan uji hipotesis (uji t).

\section{HASIL DAN PEMBAHASAN}

Statistik deskriptif disajikan untuk memberikan informasi mengenai karakteristik variabel-variabel penelitian yang dapat diamati dengan melihat besarnya nilai minimum, maksimum, rata-rata, dan simpangan baku.

Tabel 2.

Hasil Statistik Deskriptif

\begin{tabular}{|c|c|c|c|c|c|}
\hline Variabel & $\mathbf{N}$ & Min & $\operatorname{Max}$ & Mean & Std.Deviation \\
\hline $\begin{array}{l}\text { Sistem Administrasi Perpajakan } \\
\text { Modern }\left(\mathrm{X}_{1}\right)\end{array}$ & 100 & 23 & 36 & 29,5 & 2,5085 \\
\hline Pengetahuan Perpajakan $\left(\mathrm{X}_{2}\right)$ & 100 & 13 & 22 & 19,3 & 1,9984 \\
\hline Kualitas Pelayanan Fiskus $\left(\mathrm{X}_{3}\right)$ & 100 & 21 & 40 & 32,8 & 3,4398 \\
\hline $\begin{array}{l}\text { Kepatuhan Wajib Pajak Orang } \\
\text { Pribadi (Y) }\end{array}$ & 100 & 16 & 32 & 26,2 & 2,6047 \\
\hline Valid N (listwise) & 100 & & & & \\
\hline
\end{tabular}

Sumber: Data diolah, 2018

Berdasarkan Tabel 2 dapat disimpulkan bahwa jumlah pengamatan $(\mathrm{N})$ penelitian ini berjumlah 100. Variabel sistem administrasi perpajakan modern memiliki nilai minimum sebesar 23 dan nilai maksimum sebesar 36 dengan nilai rata-rata sebesar 29,5 yang apabila dibagi dengan 9 item pernyataan akan menghasilkan nilai sebesar 3,27. Hal ini berarti rata-rata responden memberikan skor 3 pada setiap item pernyataan variabel sistem administrasi perpajakan modern. Standar deviasi pada variabel ini sebesar 2,5085 yang menunjukkan bahwa standar penyimpangan data terhadap nilai rata-ratanya adalah 2,5085. 
Ni Putu Yunita Sari dan I Ketut Jati. Pengaruh...

Variabel pengetahuan perpajakan memiliki nilai minimum sebesar 13 dan nilai maksimum sebesar 22 dengan nilai rata-rata sebesar 19,3 yang apabila dibagi dengan 6 item pernyataan akan menghasilkan nilai sebesar 3,21. Hal ini berarti rata-rata responden memberikan skor 3 pada setiap item pernyataan variabel pengetahuan perpajakan. Standar deviasi pada variabel ini sebesar 1,9984 yang menunjukkan bahwa standar penyimpangan data terhadap nilai rata-ratanya adalah 1,9984 .

Variabel kualitas pelayanan fiskus memiliki nilai minimum sebesar 21 dan nilai maksimum sebesar 40 dengan nilai rata-rata sebesar 32,8 yang apabila dibagi dengan 10 item pernyataan akan menghasilkan nilai sebesar 3,28. Hal ini berarti rata-rata responden memberikan skor 3 pada setiap item pernyataan variabel kualitas pelayanan fiskus. Standar deviasi pada variabel ini sebesar 3,4398 yang menunjukkan bahwa standar penyimpangan data terhadap nilai rata-ratanya adalah 3,4398 .

Variabel kepatuhan wajib pajak orang pribadi memiliki nilai minimum sebesar 16 dan nilai maksimum sebesar 32 dengan nilai rata-rata sebesar 26,2 yang apabila dibagi dengan 8 item pernyataan akan menghasilkan nilai sebesar 3,27. Hal ini berarti rata-rata responden memberikan skor 3 pada setiap item pernyataan variabel kepatuhan wajib pajak orang pribadi. Standar deviasi pada variabel ini sebesar 2,6047 yang menunjukkan bahwa standar penyimpangan data terhadap nilai rata-ratanya adalah 2,6047. 
Tabel 3 dan Tabel 4 adalah tabel yang menyajikan informasi mengenai hasil dari uji instrumen yang telah dilakukan pada penelitian ini. Tabel 3 menyajikan hasil uji validitas, sedangkan Tabel 4 menyajikan hasil uji reliabilitas.

Tabel 3.

Hasil Uji Validitas

\begin{tabular}{clccc}
\hline No & \multicolumn{1}{c}{ Variabel } & $\begin{array}{c}\text { Kode } \\
\text { Instrumen }\end{array}$ & $\begin{array}{c}\text { Nilai Pearson } \\
\text { Correlation }\end{array}$ & Keterangan \\
\hline 1 & $\begin{array}{l}\text { Kepatuhan Wajib Pajak Orang } \\
\text { Pribadi (Y) }\end{array}$ & Y1.1- Y1.8 & $0,529-0,691$ & Valid \\
2 & $\begin{array}{l}\text { Sistem Administrasi Perpajakan } \\
\text { Modern }\left(\mathrm{X}_{1}\right)\end{array}$ & $\mathrm{X} 1.1-\mathrm{X} 1.9$ & $0,283-0,700$ & Valid \\
3 & Pengetahuan Perpajakan $\left(\mathrm{X}_{2}\right)$ & $\mathrm{X} 2.1-\mathrm{X} 2.6$ & $0,512-0,686$ & Valid \\
4 & Kualitas Pelayanan Fiskus $\left(\mathrm{X}_{3}\right)$ & $\mathrm{X} 3.1-\mathrm{X} 3.10$ & $0,512-0,666$ & Valid \\
\hline \multicolumn{2}{l}{ Sumber: Data diolah, 2018} & &
\end{tabular}

Tabel 3 menunjukkan bahwa seluruh variabel penelitian adalah valid karena nilai pearson correlation yang diperoleh lebih besar dari 0,30 .

Tabel 4.

Hasil Uji Reliabilitas

\begin{tabular}{clcc}
\hline No & \multicolumn{1}{c}{ Variabel } & Cronbach's Alpha & Keterangan \\
\hline 1 & Sistem Administrasi Perpajakan Modern & 0,716 & Reliabel \\
& $\left(\mathrm{X}_{1}\right)$ & & \\
2 & Pengetahuan Perpajakan $\left(\mathrm{X}_{2}\right)$ & 0,730 & Reliabel \\
3 & Kualitas Pelayanan Fiskus $\left(\mathrm{X}_{3}\right)$ & 0,800 & Reliabel \\
4 & Kepatuhan Wajib Pajak Orang Pribadi & 0,721 & Reliabel \\
& $(\mathrm{Y})$ & \\
\hline \multicolumn{2}{l}{ Sumber: Data diolah, 2018 }
\end{tabular}

Tabel 4 menunjukkan seluruh variabel penelitian reliabel karena nilai cronbach's alpha yang diperoleh lebih besar dari 0,70. Selanjutnya dilakukan uji asumsi klasik yang disajikan pada Tabel 5,6, dan 7, yang meliputi: uji normalitas, uji multikolienaritas dan uji heteroskedastisitas.

Tabel 5.

Hasil Uji Normalitas

\begin{tabular}{lr}
\hline & Unstandardized Residual r \\
$\mathrm{N}$ & 100 \\
Asymp.Sig. (2-tailed) & 0,125 \\
\hline Sumber: Data diolah, 2018 &
\end{tabular}


Ni Putu Yunita Sari dan I Ketut Jati. Pengaruh...

Berdasarkan Tabel 5 menunjukkan bahwa unstandardized residual memiliki nilai Asymp.Sig. (2-tailed) sebesar 0,125 yang lebih besar dari taraf signifikansi 0,05 . Hal ini berarti seluruh data dalam penelitian ini berdistribusi normal.

Tabel 6.

Hasil Uji Multikolinearitas

\begin{tabular}{lccl}
\hline \multicolumn{1}{c}{ Variabel } & \multicolumn{2}{c}{ Collinearity Statistic } & Keterangan \\
& Tolerance & VIF & \\
\hline Sistem Administrasi Perpajakan & 0,677 & 1,478 & Bebas Multikolinearitas \\
Modern $\left(\mathrm{X}_{1}\right)$ & & & \\
Pengetahuan Perpajakan $\left(\mathrm{X}_{2}\right)$ & 0,687 & 1,455 & Bebas Multikolinearitas \\
Kualitas Pelayanan Fiskus $\left(\mathrm{X}_{3}\right)$ & 0,619 & 1,615 & Bebas Multikolinearitas \\
\hline
\end{tabular}

Sumber: Data diolah, 2018

Berdasarkan Tabel 6 dapat dilihat bahwa hasil uji multikolinieritas menunjukkan masing-masing variabel bebas memiliki nilai tolerance lebih besar dari 0,10 dan nilai VIF lebih kecil dari 10. Sesuai dengan hal tersebut dapat disimpulkan bahwa tidak ada multikolinieritas antar variabel bebas dalam model regresi.

Tabel 7.

Hasil Uji Heteroskedastisitas

\begin{tabular}{lcc}
\hline \multicolumn{1}{c}{ Variabel } & Sig. & Keterangan \\
\hline Sistem Administrasi & 0,401 & Bebas Heteroskedastisitas \\
Perpajakan Modern $\left(\mathrm{X}_{1}\right)$ & & \\
$\begin{array}{l}\text { Pengetahuan Perpajakan }\left(\mathrm{X}_{2}\right) \\
\begin{array}{l}\text { Kualitas Pelayanan Fiskus } \\
\left(\mathrm{X}_{3}\right)\end{array}\end{array}$ & 0,549 & Bebas Heteroskedastisitas \\
\hline
\end{tabular}

Sumber: Data diolah, 2018

Berdasarkan Tabel 7 dapat dilihat hasil uji heteroskedastisitas menunjukkan bahwa nilai signifikansi masing-masing variabel diatas 0,05. Jadi, dapat disimpulkan bahwa model regresi dalam penelitian ini bebas dari gejala heteroskedastisitas. 
Tabel 8.

Hasil Uji Analisis Regresi Linear Berganda

\begin{tabular}{|c|c|c|c|c|c|}
\hline & $\begin{array}{r}\text { Unsta } \\
\text { Co }\end{array}$ & $\begin{array}{l}\text { dized } \\
\text { ent }\end{array}$ & $\begin{array}{c}\text { Standardized } \\
\text { Coefficient }\end{array}$ & & \\
\hline Variabel & B & $\begin{array}{c}\text { Std. } \\
\text { Error }\end{array}$ & Beta & $\mathbf{T}$ & Sig. \\
\hline$($ Constant $)$ & 7,813 & 2,873 & & 2,720 & 0,308 \\
\hline $\begin{array}{l}\text { Sistem Administrasi } \\
\text { Perpajakan Modern } \\
\left(\mathrm{X}_{1}\right)\end{array}$ & 0,320 & 0,107 & 0,308 & 2,981 & 0,004 \\
\hline $\begin{array}{l}\text { Pengetahuan } \\
\text { Perpajakan }\left(\mathrm{X}_{2}\right)\end{array}$ & 0,357 & 0,134 & 0,274 & 2,672 & 0,009 \\
\hline $\begin{array}{l}\text { Kualitas Pelayanan } \\
\text { Fiskus }\left(\mathrm{X}_{3}\right)\end{array}$ & 0,336 & 0,138 & 0,285 & 2,788 & 0,007 \\
\hline $\begin{array}{l}\text { Adjusted } \mathrm{R}^{2} \\
\mathrm{~F} \\
\text { Sig. F }\end{array}$ & & & & & $\begin{array}{c}0,714 \\
14,087 \\
0,000\end{array}$ \\
\hline
\end{tabular}

Sumber: Data diolah, 2018

Berdasarkan Tabel 8, maka persamaan regresi linear berganda yang dapat disusun sebagai berikut.

$$
Y=7,813+0,320\left(X_{1}\right)+0,357\left(X_{2}\right)+0,336\left(X_{3}\right)+e
$$

Nilai konstanta sebesar 7,813 mengandung arti jika variabel sistem administrasi perpajakan modern $\left(\mathrm{X}_{1}\right)$, pengetahuan perpajakan $\left(\mathrm{X}_{2}\right)$, dan kualitas pelayanan fiskus $\left(\mathrm{X}_{3}\right)$ dianggap konstan pada angka 0 (nol), maka kepatuhan wajib pajak orang pribadi (Y) dapat diartikan meningkat sebesar 7,813. Nilai koefisien regresi $\beta_{1}=0,320$ berarti apabila variabel sistem administrasi perpajakan modern $\left(\mathrm{X}_{1}\right)$ meningkat 1 satuan, maka kepatuhan wajib pajak orang pribadi $(\mathrm{Y})$ akan meningkat sebesar 0,320 dengan asumsi variabel lain dianggap konstan. Nilai koefisien regresi $\beta_{2}=0,357$ berarti apabila variabel pengetahuan perpajakan $\left(\mathrm{X}_{2}\right)$ meningkat 1 satuan, maka kepatuhan wajib pajak orang pribadi (Y) akan meningkat sebesar 0,357 dengan asumsi variabel lain dianggap konstan. Nilai koefisien regresi $\beta_{3}=0,336$ berarti apabila variabel kualitas pelayanan fiskus $\left(X_{3}\right)$ 
Ni Putu Yunita Sari dan I Ketut Jati. Pengaruh...

meningkat 1 satuan, maka kepatuhan wajib pajak orang pribadi (Y) akan meningkat sebesar 0,336 dengan asumsi variabel lain dianggap konstan.

Koefisien determinasi digunakan untuk mengukur sejauh mana kemampuan variabel independen dalam menerangkan variasi variabel dependen. Berdasarkan Tabel 8 menunjukkan nilai Adjusted $\mathrm{R}^{2}$ sebesar 0,714 yang memiliki arti 71,40\% variasi kepatuhan wajib pajak orang pribadi (Y) dipengaruhi oleh sistem administrasi perpajakan modern (X1), pengetahuan perpajakan (X2), dan kualitas pelayanan fiskus (X3), sedangkan $28,60 \%$ dipengaruhi oleh faktor-faktor lain yang tidak dimasukkan dalam model penelitian. Uji kelayakan model (uji F) dilakukan untuk menguji apakah variabel independen yang digunakan bersifat layak digunakan atau tidak sebagai penjelas atau prediktor. Berdasarkan Tabel 8 menunjukkan bahwa nilai signifikansi $\mathrm{F}$ adalah sebesar 0,000 yang lebih kecil dari 5 persen. Hal ini berarti variabel sistem administrasi perpajakan modern, pengetahuan perpajakan, dan kualitas pelayanan fiskus secara bersama-sama (simultan) berpengaruh pada tingkat kepatuhan wajib pajak orang pribadi, serta model dalam penelitian ini layak digunakan (fit).

Berdasarkan Tabel 8 nilai signifikansi t untuk varibel sistem administrasi perpajakan modern sebesar 0,004 yang lebih kecil dari $\alpha=0,05$. Hal ini menunjukkan hipotesis pertama dalam penelitian ini diterima yaitu, sistem administrasi perpajakan modern berpengaruh positif pada kepatuhan wajib pajak orang pribadi di Kantor Pelayanan Pajak Pratama Denpasar Timur.

Berdasarkan teori Atribusi sistem administrasi perpajakan modern merupakan faktor eksternal yang mempengaruhi individu dalam melaksanakan 
kewajiban perpajakannya. Keberadaan sistem administrasi perpajakan modern yang berbasis e-system dikatakan semakin baik apabila mampu mengakomodir wajib pajak dalam memenuhi kewajiban perpajkaannya secara efektif dan efisien. Mengingat begitu banyak kemudahan yang didapat oleh wajib pajak, maka tidak akan ada lagi alasan bagi wajib pajak melakukan tunggakan pajak.

Berdasarkan frekuensi jawaban responden yang diperoleh dari kuesioner pada variabel sistem administrasi perpajakan, pernyataan nomor 4 meraih skor tertinggi sebesar 348. Hal tersebut mengindikasikan bahwa wajib pajak telah mengaplikasikan keberadaan e-system dengan baik dalam melaksanakan kewajiban perpajakannya. Perkembangan sistem administrasi perpajakan yang semakin modern memberikan kepuasan bagi wajib pajak yang berdampak pada meningkatnya kepatuhan wajib pajak. Hal tersebut sesuai dengan penelitian yang dilakukan oleh Rahmawati (2014), Khasanah (2014), Arifin (2015) serta Wiranatha dan Rasmini (2017) yang menyimpulkan bahwa sistem administrasi perpajakan modern berpengaruh positif terhadap kepatuhan wajib pajak.

Berdasarkan Tabel 8 nilai signifikansi $\mathrm{t}$ untuk varibel pengetahuan perpajakan sebesar 0,009 yang lebih kecil dari $\alpha=0,05$. Hal ini menunjukkan hipotesis kedua dalam penelitian ini diterima yaitu, pengetahuan perpajakan berpengaruh positif pada kepatuhan wajib pajak orang pribadi di Kantor Pelayanan Pajak Pratama Denpasar Timur.

Berdasarkan teori Atribusi, pengetahuan perpajakan merupakan faktor eksternal yang mempengaruhi individu dalam melaksanakan kewajiban perpajakannya. Pengetahuan perpajakan yang dimaksud ialah wajib pajak 
Ni Putu Yunita Sari dan I Ketut Jati. Pengaruh...

memahami betul ketentuan umum dan tata cara perpajakan yang berlaku di Indonesia dan mampu mengaplikasikan pengetahuan tersebut dalam melaksanakan kewajiban perpajakan.

Berdasarkan frekuensi jawaban responden yang diperoleh dari kuesioner pada variabel pengetahuan perpajakan, pernyataan nomor 5 meraih skor tertinggi sebesar 344. Hal tersebut mengindikasikan bahwa wajib pajak telah menggunakan pengetahuan perpajakan yang dimiliki dengan cara melaksanakan kewajiban perpajakannya untuk mengoptimalkan penerimaan negara, yang nantinya dapat menunjang pembangunan nasional yang adil dan merata.

Rasshid dan Noor (2004) melakukan penelitian untuk mengevaluasi pengaruh pengetahuan perpajakan pada perilaku kepatuhan wajib pajak di Malaysia. Temuan statistiknya, menegaskan bahwa mereka yang memiliki pengetahuan pajak, cenderung memiliki tingkat kepatuhan yang lebih tinggi daripada mereka yang tidak memiliki pengetahuan pajak. Hasil penelitian tersebut diperkuat juga dengan hasil penelitian yang dilakukan oleh Oladipupo dan Obazee (2016) serta Setiyani et al. (2018) yang menyimpulkan bahwa pengetahuan perpajakan berpengaruh positif terhadap kepatuhan wajib pajak.

Berdasarkan Tabel 8 nilai signifikansi t untuk variabel kualitas pelayanan fiskus sebesar 0,007 yang lebih kecil dari $\alpha=0,05$. Hal ini menunjukkan hipotesis ketiga dalam penelitian ini diterima yaitu, variabel kualitas pelayanan fiskus berpengaruh positif pada kepatuhan wajib pajak orang pribadi di Kantor Pelayanan Pajak Pratama Denpasar Timur. 
Berdasarkan teori Atribusi, kualitas pelayanan fiskus merupakan faktor eksternal yang mempengaruhi individu dalam melaksanakan kewajiban perpajakannya. Pelayanan fiskus dapat diartikan sebagai cara petugas pajak dalam membantu mengurus atau menyiapkan segala keperluan yang dibutuhkan wajib pajak. Kualitas pelayanan yang baik dapat diukur dari kemampuan fiskus yang cakap dalam menindaklanjuti pengaduan wajib pajak, cepat tanggap dan andal dalam menyelesaikan persoalan yang dihadapi wajib pajak, dan memiliki rasa empati yang tinggi. Pelayanan fiskus yang baik serta ditunjang dengan ketersediaan fasilitas fisik di kantor pajak merupakan hal yang penting dan bisa menjadi modal utama untuk dapat menarik perhatian dan menimbulkan kepercayaan dari wajib wajib pajak dalam melaksanakan kewajiban perpajakannya, yang berdampak pada meningkatnya kepatuhan wajib pajak.

Berdasarkan frekuensi jawaban responden yang diperoleh dari kuesioner pada variabel kualitas pelayanan fiskus, pernyataan nomor 4 meraih skor tertinggi sebesar 340. Hal tersebut mengindikasikan bahwa kualitas pelayanan fiskus di Kantor Pelayanan Pajak Pratama Denpasar Timur dikatakan baik karena telah memenuhi kriteria 4K yaitu, keamanan, kenyamanan, kelancaran, dan kepastian hukum.

Pelayanan baik yang diberikan oleh fiskus secara langsung akan berdampak pada meningkatnya kepatuhan wajib pajak. Hal tersebut selaras dengan penelitian yang dilakukan oleh Wallshutzky (1984) menyatakan bahwa tingkat kepuasan wajib pajak dengan layanan di kantor pajak memiliki pengaruh pada tingkat kepatuhan mereka. Diperkuat juga dengan hasil penelitian yang dilakukan oleh 
Ni Putu Yunita Sari dan I Ketut Jati. Pengaruh...

Suari dan Rasmini (2018) serta Astina dan Setiawan (2018) yang menyimpulkan bahwa kualiats pelayanan fiskus berpengaruh positif terhadap tingkat kepatuhan wajib pajak.

Implikasi dari hasil penelitian ini mencakup dua hal, yaitu: pertama, implikasi teoritis dimana hasil penelitian ini dapat membuktikan teori yang digunakan yaitu teori Atribusi yang menjelaskan bahwa perilaku seseorang dalam memenuhi kewajiban perpajakannya disebabkan oleh faktor internal dan eksternal, dimana dalam penelitian ini faktor eksternal yang dapat mempengaruhi perilaku seseorang dalam memenuhi kewajiban perpajakannya meliputi keberadaaan sistem administrasi perpajakan modern, pengetahuan perpajakan, dan kualitas pelayanan fiskus. Hasil penelitian ini juga mengkonfirmasi bahwa variabel sistem administrasi perpajakan modern, pengetahuan perpajakan, dan kualitas pelayanan fiskus dapat mempengaruhi tingkat kepatuhan wajib pajak orang pribadi, sehingga penelitian ini dapat memberikan tambahan bukti empiris dalam menjelaskan hubungan sistem administrasi perpajakan modern, pengetahuan perpajakan, dan kualitas pelayanan fiskus pada tingkat kepatuhan wajib pajak orang pribadi.

Kedua, implikasi praktis dimana hasil penelitian ini mampu memberikan tambahan referensi, informasi, wawasan serta pemahaman yang lebih luas bagi wajib pajak orang pribadi dalam meningkatkan kepatuhan perpajakan, serta bagi Direktorat Jenderal Pajak khususnya berkaitan dengan sistem administrasi perpajakan modern, pengetahuan perpajakan, kualitas pelayanan fiskus, yang nantinya dapat digunakan dalam mengambil keputusan serta menentukan 
kebijakan-kebijakan di masa yang akan datang sehingga dapat meningkatkan kinerja organisasi.

\section{SIMPULAN}

Berdasarkan hasil penelitian yang dilaksanakan di KPP Pratama Denpasar Timur tentang kepatuhan wajib pajak orang pribadi, maka dapat disimpulkan beberapa hal. 1) Sistem administrasi perpajakan modern berpengaruh positif pada kepatuhan wajib pajak orang pribadi. 2) Pengetahuan perpajakan berpengaruh positif pada kepatuhan wajib pajak orang pribadi. 3) Kualitas pelayanan fiskus berpengaruh positif pada kepatuhan wajib pajak orang pribadi.

Berdasarkan hasil penelitian serta simpulan, adapun saran yang dapat diberikan untuk penelitian ini adalah sebagai berikut. Pertama, bagi KPP Pratama Denpasar Timur sudah memberikan pelayanan pajak dengan baik, sehingga diharapkan kualitas pelayanan yang baik ini dapat dipertahankan dan lebih ditingkatkan guna memberikan kepuasan dan kenyamanan bagi wajib pajak. Selain hal tersebut, dalam upaya meningkatkan sistem administrasi perpajakan modern dan pengetahuan perpajakan di Kantor Pelayanan Pajak Pratama Denpasar Timur, sebaiknya petugas pajak secara rutin melakukan sosialisasi kepada wajib pajak. Hal tersebut dilakukan agar wajib pajak menyadari keberadaan e-system dan cara penggunaannya. Sosialisasi mengenai ketentuan umum dan tata cara perpajakan yang berlaku di Indonesia juga diharapkan dapat meningkatkan pemahaman wajib pajak, sehingga mendorong kesadaran dan kepatuhan wajib pajak dalam memenuhi kewajiban perpajakannya. 
Ni Putu Yunita Sari dan I Ketut Jati. Pengaruh...

Kedua, penelitian ini juga terbatas hanya meneliti kepatuhan wajib pajak orang pribadi di KPP Pratama Denpasar Timur. Bagi peneliti selanjutnya yang tertarik untuk melakukan kajian di bidang yang sama disarankan dapat menambah jumlah sampel dengan cara memperluas wilayah penelitian sehingga hasil penelitian dapat digeneralisasikan, serta obyek penelitian yang tidak hanya terbatas pada wajib pajak orang pribadi. Penambahan variabel-variabel lain yang dianggap dapat berpengaruh terhadap kepatuhan wajib pajak juga diharapkan pada penelitian selanjutnya.

\section{REFERENSI}

Ameur, F., \& Tkiouat, M. (2016). A contribution of expected utility theory in taxpayers' behavior modeling. International Journal of Economics and Financial Issues, 6(3), 1217-1224. Retrieved from https://www.scopus.com/inward/record.uri?eid=2-s2.084982131433\&partnerID=40\&md5=e61c5dd1c4cb0cdeaaa1b7b9e78f846a

Andinata, M. C. (2015). Analisis Faktor-Faktor yang Mempengaruhi Kepatuhan Wajib Pajak Orang Pribadi dalam Membayar Pajak (Studi kasus Pada KPP Pratama Surabaya Rungkut di Surabaya). Jurnal Ilmiah MahasiswaUniversitas Surabaya, 2(2).

Anggraeni, R. (2016). Evaluasi Sistem Administrasi Perpajakan Terhadap Kepatuhan Wajib Pajak. Jurnal Ilmu Dan Riset Akuntansi, 5(5).

Arifah, Andini, R., \& Raharjo, K. (2017). Pengaruh Modernisasi Sistem Administrasi Perpajakan, Kualitas Pelayanan, Pengetahuan Perpajakan, Sanksi Perpajakan dan Kesadaran Perpajakan Terhadap Kepatuhan Wajib Pajak Orang Pribadi pada Kantor Pelayanan Pajak Pratama Demak Selama Periode (2012-2016). Jurnal Akuntansi, 1-16.

Arifin, A. . (2015). Pengaruh Modernisasi Sitem Administrasi Perpajakan, Kesadaran Perpajakan, Sanksi Pajak dan Pelayanan Fiskus terhadap Kepatuhan Wajib Pajak Orang Pribadi.

Astina, I. P. S., \& Setiawan, P. E. (2018). Pengaruh Pemahaman Peraturan Perpajakan, Kualitas Pelayanan Fiskus dan Kesadaran Wajib Pajak Terhadap Tingkat Kepatuhan WPOP. E-Jurnal Akuntansi Universitas Udayana, 23(1), 
Carolina, V. (2009). Pengetahuan Pajak. Jakarta: Salemba Empat.

Çevik, S., \& Yeniçeri, H. (2013). The Relationship between Social Norms and Tax Compliance: The Moderating Role of the Effectiveness of Tax Administration. International Journal of Economic Sciences, 2(3), 166-180.

Das-gupta, A. (2004). Tax Administration Reform and Taxpayer Compliance in India, 575-600.

Deny, S. (2017). 2.900 WP Tunggak Kewajiban Pajak Sepanjang 2006-2017. Retrieved from http://www.liputan6.com/bisnis/read/3200910/2900-wptunggak-kewajiban-pajak-sepanjang-2006-2017

Fasmi, L., \& Misra. (2012). Pengaruh Modernisasi Sistem Administrasi Perpajakan Terhadap Kepatuhan Pengusaha Kena Pajak di Kantor Pelayanan Pajak (KPP) Pratama Padang. Akuntansi, 15.

Ghozali, I. (2016). Aplikasi Analisis Multivariate Dengan Program IBM dan SPSS 21. In Aplikasi Analisis Multivariate dengan Pogram iIBM SPSS 21 (p. 113). Semarang: Badan Penerbit Universitas Diponegoro. https://doi.org/10.2307/1579941

Hasseldine, J., Holland, K., \& Van Der Rijt, P. (2009). The Management of Tax Knowledge. Engineering and Technology (Vol. 0). Retrieved from http://eprints.soton.ac.uk/80383/

Helhel, Y., \& Ahmed, Y. (2014). Factors Affecting Tax Attitudes and Tax Compliance: A Survey Study in Yemen. European Journal of Business and Managemen Akdeniz University, 6(22), 48-58.

Hidayatulloh, H. A. (2013). Pengaruh Kualitas Pelayanan Pajak dan Pengetahuan Pajak Terhadap Kepatuhan Wajib Pajak (Survey pada KPP Pratama Bandung Cicadas).

Hunt, D. P. (2003). The Concept of Knowledge and How to Measure It. Journal of Intellectual Capital, 4(1), 100-113. https://doi.org/10.1108/14691930310455414

James, S., \& Alley, C. (2004). Tax Compliance, and Tax Administration. Journal of Finance and Management in Public Services, 2(2), 27-42.

Kasippilai, J. (2000). Taxpayer Knowledge Index as A Clue For Non-Compliance. Journal on Pakistan's Taxation Laws, 81(3). 
Ni Putu Yunita Sari dan I Ketut Jati. Pengaruh...

Khasanah, S. N. (2014). Pengaruh Pengetahuan Perpajakan, Modernisasi Sistem Administrasi Perpajakan, Dan Kesadaran Wajib Pajak Terhadap Kepatuhan Wajib Pajak Pada Kantor Wilayah Direktorat Jenderal Pajak Daerah Istimewa Yogyakarta Tahun 2013.

Kirchler, E., \& Wahl, I. (2010). Tax Compliance Inventory TAX-I: Designing an Inventory for Surveys of Tax Compliance. Journal of Economic Psychology, 31,331 .

Kusuma, K. C. (2016). Pengaruh Kualitas Pelayanan Pajak, Pemahaman Peraturan Perpajakan Serta Sanksi Perpajakan Terhadap Kepatuhan Wajib Pajak Orang Pribadi Dalam Membayar Pajak Tahun 2014 (Studi Kasus Pada Wajib Pajak Yang Terdaftar Di Kantor Pelayanan Penyuluhan Dan Konsulta. Jurnal Akuntansi.

Maisiba, G. J., \& Atambo, W. (2016). Effects of Electronic-Tax System on the Revenue Collection Efficiency of Kenya Revenue Authority: A Case of Uasin Gishu County. Imperial Journal of Interdisciplinary Research (IJIR), 2(4), 815-827.

Mardiasmo. (2016). Perpajakan Edisi Terbaru 2016. Yogyakarta: Penerbit Andi.

Murti, H. W. (2014). Pelayanan Fiskus dan Pengetahuan Perpajakan Terhadap Kepatuhan Wajib Pajak Orang Pribadi Di Kota Manado. Jurnal EMBA, 2(3), 389-398.

Nasucha, C. (2004). Reformasi Adminstrasi Publik Teori dan Praktik. Jakarta: PT Gramedia Widiasarana Indonesia.

Oladipupo, A. O., \& Obazee, U. (2016). Tax Knowledge , Penalties and Tax Compliance in Small and Medium Scale Enterprises in Nigeria. IBusiness, 8(1), 1-9. https://doi.org/10.4236/ib.2016.81001

Prananti, N. P. I., \& Rasmini, N. K. (2014). Pengaruh Modernisasi Administrasi Perpajakan, Pelayanan Fiskus Dan Penggunaan E-Spt Pada Kepatuhan Pajak. E-Jurnal Akuntansi Universitas Udayana, 6(1).

Rahayu, S. K. (2010). Perpajakan Indonesia: Konsep \& Aspek Formal. Yogyakarta: Graha Ilmu.

Rahmawati, Y. A. (2014). Analisis Modernisasi Sistem Administrasi Perpajakan dan Pengetahuan Perpajakan terhadap Kepatuhan Pengusaha Kena Pajak.

Robbins, S. P., \& Judge, T. A. (2008). Perilaku Organisasional. Jakarta: Salemba Empat.

Saad, N. (2014). Tax Knowledge, Tax Complexity and Tax Compliance: 
Taxpayers' View. Procedia - Social and Behavioral Sciences, 109(1), 10691075. https://doi.org/10.1016/j.sbspro.2013.12.590

Safri. (2013). Pengaruh Kesadaran Wajib Pajak Terhadap Kepatuhan Wajib Pajak Orang Pribadi Yang Melakukan Pekerjaan Bebas (Studi Di Wilayah Kpp Pratama Yogyakarta). Jurnal Akuntansi.

Santoso, S. N. (2015). Pengaruh Pengetahuan Pajak, Kesadaran Wajib Pajak, Dan Sanksi Pajak Terhadap Kepatuhan Wajib Pajak (Studi Pada Wajib Pajak Orang Pribadi Di Kantor Pelayanan Pajak Kepanjen). Jurnal Mahasiswa Perpajakan, 6(1).

Savilla, P., Dzulkirom, \& Zahroh, Z. . (2018). Pengaruh Administrasi Perpajakan dan Sumber Daya Manusia Terhadap Tingkat Kepatuhan Wajib Pajak (Studi Kasus Pada Wajib Pajak Di KPP Pratama Malang Selatan), 55(3), 48-54.

Serem, Wilberfore;Robert, Kinanga;Phillip, O. (2017). The Effect of Tax System Simplicity on Tax Compliance Among the Rental Income Earners in Kenya. European Journal, 5(5), 13-22.

Setiyani, N. M., Andini, R., \& Oemar, A. (2018). Pengaruh Motivasi Wajib Pajak dan Pengetahuan Perpajakan Terhadap Kepatuhan Wajib Pajak Orang Pribadi dengan Kesadaran Wajib Pajak Sebagai Variabel Intervening. Jurnal Akuntansi, 1-18.

Suari, N. L. E. V., \& Rasmini, N. K. (2018). Pemahaman Peraturan, Efektivitas Sistem, Kewajiban Moral, Kualitas Pelayanan, Sanksi Perpajakan Pada Kemauan Ikut Tax Amnesty. E- Jurnal Akuntansi Universitas Udayana, 22(1). https://doi.org/https://doi.org/10.24843/EJA.2018.v22.i01.p05

Supadmi, N. L. (2009). Meningkatkan Kepatuhan Wajib Pajak Melalui Kualitas Pelayanan. Jurnal Ilmiah Akuntansi dan Bisnis. JIAB, 4, 2.

Suparman, R. A. (2007). Sistem Administrasi Perpajakan Modern. Retrieved from http://pajaktaxes.blogspot.co.id/2007/04/sistem-administrasi-perpajakanmodern.html

Syahril, F. (2013). Pengaruh Tingkat Pemahaman Wajib Pajak dan Kualitas Pelayanan Fiskus Terhadap Tingkat Kepatuhan Wajib Pajak PPh Orang Pribadi (Studi Empiris Pada KPP Pratama Kota Solok).

Wallshutzky, I. G. (1984). Possible Causes of Tax Evasion. Journal of Economic Psychology, 5(1), 371-384.

Walsh, K. (2012). Understanding taxpayer behaviour - new opportunities for tax administration. Economic and Social Review, 43(3), 451-475. 
Ni Putu Yunita Sari dan I Ketut Jati. Pengaruh...

Wirenungan, O. L. (2013). Sosialisasi Perpajakan, Pelayanan Fiskus dan Sanksi Perpajakan terhadap Kepatuhan WPOP di KPP Manado dan KPP Bitung. Jurnal EMBA, 1(3), 960-970. https://doi.org/ISSN 2303-1174

Yamit, Z. (2002). Manajemen Kualitas Produk dan Jasa. Jakarta: Salemba Empat.

Yuliasari, W. S. (2015). Pengaruh Sosialisasi Perpajakan, Pelayanan Fiskus, dan Sanksi Terhadap Kepatuhan Wajib Pajak Orang Pribadi (Studi pada Wajib Pajak Orang Pribadi di KPP Pratama Ponorogo). Jurnal Administrasi Bisnis - Perpajakan (JAB), 4(2). 